\title{
Late summer protein supplementation for yearling cattle
}

\author{
E. E. GRINGS, R. E. SHORT, M. R. HAFERKAMP, AND R. K. HEITSCHMIDT
}

Authors are Research Animal Scientist, Research Physiologist (retired), Rangeland Scientist, and Supervisory Rangeland Scientist, USDA-ARS, Fort Keogh Livestock and Range Research Laboratory, Miles City, Mont. 59301.

\section{Abstract}

Three studies were conducted to evaluate late summer protein supplementation for growing steers on Northern Great Plains rangeland. In Experiment 1 , crossbred yearling steers $(N=80$ per year, mean initial live-weight $=275 \mathrm{~kg}$ ) were allotted to 1 of 2 treatments replicated in 3 pastures in each of 3 years. Treatments were summer-long grazing with or without protein supplementation in late summer. Protein supplement $(26 \%$ crude protein) was fed at a rate of $1.68 \mathrm{~kg}$ (dry matter basis) every third day. In 1995, a third treatment was added to additional pastures consisting of $1.62 \mathrm{~kg}$ (dry matter basis) of a $40 \%$ crude protein supplement fed every third day. There was no weight gain response to protein supplementation. In Experiment 2, yearling steers grazing rangeland from May to September were fed either no supplement, $1.5 \mathrm{~kg}$ of a $22 \%$ crude protein safflower meal-based supplement, $1.2 \mathrm{~kg}$ of $26 \%$ soybean meal-based supplement or $1.2 \mathrm{~kg}$ of a $26 \%$ safflower and soybean meal-based supplement every third day in late summer. Live-weight gain, forage intake, and digestibility were not affected by supplementation. A third experiment using ruminally cannulated steers fed grass hay and the 3 protein supplements based on safflower and soybean meals showed an increase in ruminal ammonia concentrations but no other appreciable change in ruminal fermentation with protein supplementation. Supplementation with as much as 648 grams of protein every third day was not a viable means to increase gains of steers grazing Northern Great Plains rangelands during late summer under the conditions of this experiment.

Key Words: grazing management, beef cattle

Rates of live-weight gain of yearling cattle grazing Northern Great Plains rangelands in late summer can be low due to limitations in forage quantity and quality (Heitschmidt et al. 1993). Currie et al. (1989) monitored daily live-weight changes of steers and reported that gains peaked in late July to early August with some steers losing weight during late summer. One strategy to maintain gains during late summer may be to provide supplemental nutrients. Previously, we observed that providing a soybean meal-based supplement throughout summer increased weight

The authors express appreciation to Norm Bellows, Richard Bonine, JoAnne Gresens, Byron Hould, Caralea Leidholt, Susan Reil, and Brooke Shipp for assistance with this research.

This paper is a contribution from the U.S. Department of Agriculture, Agricultural Research Service and the Montana Agricultural Experiment Station, Miles City, Mont. U.S. Department of Agriculture, Agricultural Research Service, Northern Plains Area, is an equal opportunity/affirmative action employer, and all agency services are available without discrimination.

Manuscript accepted 6 Oct. 03.

\section{Resumen}

Se condujeron tres estudios para evaluar la suplementación protéica a fines del verano para novillos en crecimiento en un pastizal de las Grandes Planicies del Norte. En el experimento 1 novillos cruzados de un año de edad $(N=80$ por año, media inicial de peso vivo $=275 \mathrm{~kg}$ ) se asignaron a uno de dos tratamientos repetidos en tres potreros en cada uno de tres años. Los tratamientos fueron apacentamiento durante el verano con y sin suplementación protéica a fines del verano. El suplemento protéico $(26 \%$ de proteína cruda) se proporciona a una tasa de $1.68 \mathrm{~kg}$ (en base a materia seca) cada tres días. En 1995, un tercer tratamiento se agregó en potreros adicionales consistente de 1.62 kg (en base a materia seca) de un suplemento con $40 \%$ de proteína cruda ofrecido cada tercer día. No hubo respuesta en la ganancia de peso a la suplementación protéica. En el Experimento 2, novillos de un año apacentando el pastizal de Mayo a Septiembre fueron alimentados con y sin suplementación, $1.5 \mathrm{~kg}$ de un suplemento a base de harina de cártamo con $22 \%$ de proteína cruda, $1.2 \mathrm{~kg}$ de un suplemento a base de harina de soya con $26 \%$ de proteína cruda, $1.2 \mathrm{~kg}$ de un suplemento a base de harina de soya y cártamo con $26 \%$ de proteína cruda, el suplementos se les ofreció cada tercer día a fines de verano. La ganancia de peso vivo, el consumo de forraje y la digestibilidad no fueron afectadas por la suplementación. En un tercer experimento novillos con cánula ruminal, alimentados con heno de zacate y los tres suplementos de protéicos basados en harina de soya y cártamo, mostraron un incremento en la concentración ruminal de amonio, pero no hubo otros cambios apreciables en la fermentación ruminal producto de la suplementación protéica. Bajo las condiciones de este experimento la suplementación con $648 \mathrm{~g}$ de proteína como máximo, ofrecida cada tercer día a fines del verano, no fue un medio viable para incrementar las ganancias de peso de los novillos apacentando los pastizales de las Grandes Planicies del Norte a fines del verano.

gain of growing cattle and was an economical means of improv= ing production (Grings et al. 1994).

Safflower meal may be a cost effective protein source for producers in parts of the Northern Great Plains. Only a limited amount of research has been conducted with safflower meal to evaluate its use as a protein supplement for grazing cattle. Protein supplementation may improve animal performance through improved intake and/or digestibility (Petersen 1987) and it is helpful to understand these relationships to develop effective supplementation programs. In this series of studies, our objectives were to test the effect of providing protein supplements to growing steers after rangeland forage quality began to decline in late summer and to evaluate the effects of the supplementation protocol on intake, digestibility, and ruminal fermentation. 


\section{Materials and Methods}

This research was conducted at the Fort Keogh Livestock and Range Research Laboratory near Miles City, Mont. $\left(46^{\circ} 22^{\prime} \mathrm{N} 105^{\circ} 5^{\prime} \mathrm{W}\right)$. Climate is continental and semi-arid with vegetation dominated by western wheatgrass [Pascopyrum smithii (Rydb.) Love], threadleaf sedge [Carex filifolia Nutt.], needle and thread [Stipa comata Trin. and Rupr.], blue grama [Bouteloua gracilis (H.B.K.)], and downy [Bromus tectorum L.] and Japanese bromes [B. japonicus Thunb.]. Average annual precipitation for the area is 338 mm with $60 \%$ received during the 150 day, mid-April to mid-September growing season. Total annual precipitation during the experimental period was $473 \mathrm{~mm}$ in 1993, $249 \mathrm{~mm}$ in 1995, and $325 \mathrm{~mm}$ in 1995 (NOAA 1993-1995).

\section{Experiment 1}

Experiment 1 was conducted to evaluate the effect of late summer protein supplementation on live-weight gain in yearling cattle grazing rangeland. During each of 3 years (1993-1995), 80 crossbred yearling steers of British-type breeding (mean initial live-weight $=275 \mathrm{~kg}$ ) were allotted to 1 of 2 treatments replicated in 3 pastures (6 pastures total) in a completely random design. Before the experiment, steers were implanted with a 200-day estradiol implant. Steers grazed from mid-May through early September (1994) or early October (1993 and 1995) depending on the cattle owner's marketing strategy. Pasture size ranged from 36 to 79 hectares. Stocking rate averaged 26 steer day ha ${ }^{-1}$. Stocking rate was based on SCS (1983) guidelines for range sites in good condition. Animal numbers per pasture were assigned based on both pasture size and pasture range site composition, therefore, the number of steers per hectare was not equal across pastures.

Steers were weighed initially and then about every 14 day on a non-shrunk basis. Steers generally watered at mid-afternoon and were not allowed access to water the morning of weighing. On weigh days steers were herded to a centrally located corral and weighing facility beginning at about 0600 hours so that minimal grazing would have occurred in the morning before weighing.

Steers in the control treatment received no supplemental feed, whereas those in a second treatment received protein supplementation after forage quality declined in late summer when cool-season grasses became dormant. Decisions concerning the start of protein supplementation were based on biweekly weight changes and visual estimates of forage quality and quantity. Forages at this location senesce in late summer with a visible change in the relative amount of live and dead material present indicating a decline in protein and energy values (Heitschmidt et al. 1995). The timing of grazing and supplementation varied among years due to differences in forage conditions (Table 1).

Table 1. Dates of the beginning and ending of the grazing periods and time of supplementation for Experiments 1 and 2.

\begin{tabular}{llcr}
\hline \hline Year & $\begin{array}{c}\text { Start of } \\
\text { grazing }\end{array}$ & $\begin{array}{c}\text { Supplementation } \\
\text { begins }\end{array}$ & $\begin{array}{c}\text { End of } \\
\text { grazing }\end{array}$ \\
\hline 1993 & 19 May & 16 Aug. & 4 Oct. \\
1994 & 17 May & 16 Jul. & 8 Sep. \\
1995 & 15 May & 17 Jul. & 26 Sep. \\
\hline
\end{tabular}

Steers receiving protein supplement were group-fed every third day. Previous research has indicated that growth rate in cattle does not differ when protein is supplemented at infrequent (2 to 7-day) intervals (McIlvain and Shoop 1962). The protein supplement was a barley-soybean meal-based 0.6-cm diameter pellet containing $25.8 \% \mathrm{CP}$ (Table 2) fed at $1.68 \mathrm{~kg} \mathrm{DM}$ every third day, providing $433 \mathrm{~g}$ of additional CP every third day. Cattle were herded to a feeding site at a corral facility within each pasture for supplementation. The feeding site was near the water source that all cattle visited at least once daily. Cattle not receiving supplements were left undisturbed, allowing any disruption of grazing behavior due to supplementation to be considered an impact of supplementation. In 1995 , a third treatment was added in 3 additional pastures to determine if a response might be observed if additional protein was fed. The third treatment was a protein supplement containing $40 \%$ CP (Table 2) fed at $1.62 \mathrm{~kg}$ DM every third day and provided $648 \mathrm{~g} \mathrm{CP}$ every third day with the same amount of energy as the moderate protein supplement. Steers had ad libitum access to a trace mineralized salt mix.

Analysis of variance of live-weight and gain data comparing control to the moderate level of protein supplement in all 3 years was conducted with a completely random model that included treatment, year, and pasture within treatment (SAS 1989). Treatment means were tested with the pasture within treatment mean square as the error term. Year and the year by treatment interactions effects were tested with the residual error term. A second analysis was conducted on the live-weight gains from year 3 only so that the high protein treatment could be compared to the other treatments within that year. The model for this analysis included treatment and pasture within treatment effects. Treatment means were tested with the pasture within treatment mean square as the error term. Results of these 2 analyses are presented separately and analysis of the full 3-year experiment is not affected by the addition of the third treatment in 1995 .

\section{Experiment 2}

Experiment 2 was conducted to evaluate the impact of protein supplementation on intake and digestibility of forage grazed

Table 2. Ingredient (as fed basis) and chemical (dry matter; DM basis) composition of supplements containing soybean meal (SBM) and /or safflower meal (SFM) fed to yearling steers grazing rangeland in late summer (Experiments 1 and 2) and to ruminally cannulated steers fed hay in the drylot (Experiment 3).

\begin{tabular}{|c|c|c|c|c|}
\hline Ingredient & $\begin{array}{c}\text { Moderate } \\
\mathrm{CP}^{1}\end{array}$ & $\begin{array}{c}\text { High } \\
\mathrm{CP}^{2}\end{array}$ & $\mathrm{SFM}^{3}$ & $\begin{array}{l}\mathrm{SFM}^{+} \\
\mathrm{SBM}^{3}\end{array}$ \\
\hline Ingredient Composition & \multicolumn{4}{|c|}{ (\% of DM) } \\
\hline Barley & 50.3 & 13.3 & 12.2 & 28.0 \\
\hline Soybean meal & 40.0 & 77.9 & & 19.2 \\
\hline Safflower meal & & & 80.0 & 44.1 \\
\hline Molasses & 5.0 & 4.2 & 5.0 & 5.0 \\
\hline Monocalcium phosphate & 1.9 & 1.5 & & 0.9 \\
\hline Bentonite & 2.5 & 2.5 & 2.5 & 2.5 \\
\hline Calcium oxide & 0.3 & 0.3 & 0.3 & 0.3 \\
\hline \multicolumn{5}{|l|}{ Chemical Composition } \\
\hline $\mathrm{DM}, \%$ & 92.1 & 89.2 & 92.8 & 92.6 \\
\hline Ash, \% of DM & 9.7 & 10.8 & 9.9 & 12.1 \\
\hline Crude protein, \% of DM & 25.8 & 40.0 & 22.0 & 25.8 \\
\hline Neutral detergent fiber, $\%$ of $\mathrm{DM}$ & 16.9 & 14.4 & 49.5 & 37.0 \\
\hline Acid detergent fiber, $\%$ of DM & 7.9 & 6.3 & 36.0 & 25.2 \\
\hline In vitro organic matter digestibility, $\%$ & 89.7 & 92.9 & 68.4 & 56.8 \\
\hline
\end{tabular}

Supplement used in Experiments 1, 2, and 3

${ }^{2}$ Supplement used in Experiment 1 in 1995 only

${ }^{3}$ Supplement used in Experiments 2 and 3 
by yearling steers and to determine any differences in this effect due to protein source. In each of 2 years, 56 crossbred yearling steers were allotted to 1 of 4 treatments in 3 pastures in a randomized complete block design with pasture as the block. Pastures were 71 (16 steers), 83 (20 steers), and 90 (20 steers) hectares.

Steers were individually fed supplement once every third day. Steers received a 200day estradiol implant at the beginning of the experiment. Treatments were 1) control, 2) $1.5 \mathrm{~kg}$ safflower-based protein supplement (SFM), 3) $1.2 \mathrm{~kg}$ soybean meal-based supplement (SBM), and 4) $1.2 \mathrm{~kg}$ safflower and soybean meal-based supplement (Table 2). Protein supplementation was started after forage quality began to decline late August 1993 and mid-July 1994.

Fecal output was measured 4 times each summer using total collection of feces. Two steers from each treatment-pasture combination (24 steers per year) were fitted with fecal collection harnesses for 6 days. Fecal bags were emptied once each day. Feces were weighed, a sample was collected, dried, and weekly composites (by animal) were made on an equal DM basis. The same 24 steers were used for each collection period in a year.

Intake was estimated from fecal output and diet digestibility determined using indigestible NDF (INDF; Cochran et al. 1986) as an internal digestibility marker. Forage intake was estimated by subtracting out the contribution of the supplement to fecal INDF.

One steer in 1993 and 2 steers in 1994 consistently did not eat all of their protein supplements and their data was excluded from all analyses. Data were analyzed using the General Linear Models procedure of SAS (1989) with a randomized complete block model that included pasture as the block and also included supplement type, year, month of sampling, and associated interactions. Individual feeding of steers allowed individual steers to be used as the experimental unit. Orthogonal contrasts used to compare treatments were control vs supplement, SFM supplement vs SBM supplement, and the combination of SFM and SBM vs the average of them individually.

\section{Forage and Diet Sampling for Studies 1 and 2}

Standing crop of pastures used for Experiment 1 were sampled before grazing, at the beginning of the supplementation period, and at the end of grazing by double sampling techniques. Two range sites per pasture were chosen for sam- pling. Three total range sites were sampled as not all pastures were comprised of the same range sites. These range sites comprised 24 to $73 \%$ of these pastures.

For Experiment 2, standing crop was estimated monthly, corresponding to timing of intake measures. Two range sites per pasture were sampled and the 3 pastures used in this experiment had similar range sites. The 2 range sites comprised 34 to $48 \%$ of these pastures.

For double sampling, 4 non-random reference plots $\left(0.25 \mathrm{~m}^{2}\right)$ per range site were chosen based on a range of biomass from least to most abundant. Additionally 10 random plots per site per pasture were estimated. The 4 reference plots and the every fifth plot were clipped for calibration of the estimates. Herbage was clipped to the ground, sorted by grass and forbs, dried at $55^{\circ} \mathrm{C}$ for 48 hours, and weighed. The non-random reference plots were not included in standing crop estimates for the pasture. Samples were composited within site and saved for chemical analysis. Chemical analysis on herbage included dry matter, ash (both AOAC 1990), crude protein (Hach 1987), neutral detergent fiber (NDF; Robertson and Van Soest 1977) and in vitro organic matter digestibility (IVOMD; Tilley and Terry 1963). Due to compositing of samples, there was no statistical analysis conducted on the forage quantity and quality estimates.

Diet quality was determined in representative pastures using esophageally cannulated yearling heifers $(N=6$ in 1993, 4 in 1994, and 7 in 1995). Pastures used to estimate diet quality in 1993 and 1994 were the 3 pastures used in experiment 2. Two pastures were used in 1995, representing control and supplement treatments. Cannulated yearling heifers were held overnight without food, but with access to water. Sampling began about 0700 hours and heifers were allowed to graze for 30 to 45 min using plastic screen-bottomed collection bags. Two pastures were sampled each day and each pasture was sampled on 2 non-consecutive days within a week in a varied order to prevent any potential effects that pasture sampling order could have on diet selection patterns. Heifers were allowed to graze freely and were not limited to specific range sites. Samples were placed immediately on ice and returned to the laboratory where samples from each pasture were composited across days. Samples were frozen, lypholyzed, and ground to pass a 1-mm screen in a Wiley mill. Analysis included dry matter (DM), ash, acid detergent fiber (AOAC
1990), acid detergent lignin, acid detergent insoluble nitrogen (Goering and Van Soest 1970), crude protein (CP; Hach 1987), neutral detergent fiber, and in vitro organic matter digestibility without supplemental nitrogen (Blümmel et al. 2000). Indigestible NDF (INDF) was determined on diet samples for use as a digestibility marker in Experiment 2.

\section{Experiment 3}

A 60-day drylot experiment was conducted to evaluate the impact of supplementation on ruminal fermentation characteristics of steers fed protein supplements along with chopped grass hay. Hay quality averaged $9.1 \% \mathrm{CP}$, which was similar to the forage quality in the supplementation period for the grazing trails in 1993 and 1994. Four steers $($ mean live-weight $=381$ $\mathrm{kg}$ ) that had been used for intake measurements in 1994 were ruminally cannulated after the grazing experiment was completed. Steers were used in a 4- $x$ 4- Latin square experimental design with a control and 3 supplementation treatments. Supplements were the same as those fed in Experiment 2, with the protein source being soybean meal, safflower meal, or a combination of the 2 protein meals. Supplements were provided every third day at a rate of $0.8 \mathrm{~g} \mathrm{CP} \mathrm{kg}^{-1} \mathrm{BW}$. Steers were fed each diet for a 10-day adaptation period followed by 5-day of sample collection. At 0730 on the day of supplement feeding, 0 -hour samples were collected and a $210 \mathrm{ml}$ dose of a CoEDTA marker (4.89 $\mathrm{mg} \mathrm{Co} \mathrm{liter}^{-1}$ ) was placed into the rumen. Steers were then fed supplement and given access to chopped hay. Rumen samples were collected $2,4,8,12,24,26$, $28,32,48,50,52,56,72$, and 80 hours later. Samples were immediately measured for $\mathrm{pH}$ and then filtered through 4 layers of cheesecloth. Two $\mathrm{ml}$ of $20 \% \mathrm{H}_{2} \mathrm{SO}_{4}$ were added to $100 \mathrm{ml}$ of ruminal fluid, followed by centrifugation at $10,000 \times \mathrm{g}$ for $30 \mathrm{~min}$. Samples were then frozen until analysis. Analysis on ruminal fluid included ammonia (Weatherburn 1967), volatile fatty acids by gas chromatography (HP 5890, Chromosorb WAW 80/100 packed column), and Co by atomic absorption spectrophotometry (Perkin Elmer Model 5000).

Data were analyzed using the General Linear Models procedure of SAS (SAS 1989) as $4 \times 4$ Latin square with a split plot used to evaluate time of sampling. The model included steer, period, diet, diet within steer by period, sampling time, and sampling time by diet interaction. The 
Table 3. Forage standing crop quantity $( \pm \mathrm{SE})$ and quality in pastures used in Experiments 1 and 2 for control and supplemented steers.

\begin{tabular}{|c|c|c|c|c|c|c|c|c|}
\hline \multirow[b]{2}{*}{ Time of sampling } & \multicolumn{2}{|c|}{$\begin{array}{c}\text { Forage quantity } \\
\text { in pastures grazed by }\end{array}$} & \multirow[b]{2}{*}{$\begin{array}{c}\text { Steers in } \\
\text { Experiment } 2\end{array}$} & \multicolumn{5}{|c|}{ Forage quality } \\
\hline & Control steers & $\begin{array}{l}\text { Supplemented } \\
\text { steers }\end{array}$ & & IVOMD & $\mathrm{CP}$ & NDF & ADF & $\overline{\mathrm{ADL}}$ \\
\hline 1993 & \multicolumn{2}{|c|}{-..-- $\left(\mathrm{kg} \mathrm{ha}^{-1}\right)-\cdots$} & & $(\%)$ & \multicolumn{4}{|c|}{ (\% of OM)-1. } \\
\hline Pre-Grazing & $1576 \pm 53$ & $1504 \pm 59$ & $1575 \pm 76$ & 60.3 & 9.4 & 78.9 & 47.9 & 5.2 \\
\hline Mid-Grazing & $1888 \pm 96$ & $1826 \pm 89$ & $1682 \pm 59$ & 59.8 & 8.0 & 80.4 & 49.0 & 5.5 \\
\hline End of grazing & $1965 \pm 70$ & $1735 \pm 81$ & $1571 \pm 88$ & 55.5 & 6.6 & 83.3 & 51.0 & 6.2 \\
\hline \multicolumn{9}{|l|}{1994} \\
\hline Pre-Grazing & $2093 \pm 89$ & $1946 \pm 77$ & $1641 \pm 79$ & 59.1 & 7.6 & 81.1 & 48.2 & 5.6 \\
\hline Mid-Grazing & $1896 \pm 86$ & $1684 \pm 81$ & $1974 \pm 79$ & 50.1 & 5.4 & 82.5 & 48.6 & 5.7 \\
\hline End of grazing & $1919 \pm 79$ & $1872 \pm 62$ & $1661 \pm 78$ & 49.7 & 5.1 & 83.0 & 50.4 & 5.7 \\
\hline \multicolumn{9}{|l|}{1995} \\
\hline Pre-Grazing & $1740 \pm 82$ & $1488 \pm 53$ & - & 56.0 & 7.6 & 75.2 & 48.0 & 5.5 \\
\hline Mid-Grazing & $1649 \pm 73$ & $1474 \pm 46$ & - & 46.9 & 5.3 & 78.6 & 46.0 & 5.7 \\
\hline End of grazing & $1828 \pm 97$ & $1573 \pm 63$ & - & 43.3 & 5.1 & 87.1 & 53.1 & 6.8 \\
\hline
\end{tabular}

effect of diet was tested using the diet within steer by period mean square as the error term. Sampling time and the sampling time by diet interaction were tested with the residual error. Orthogonal contrasts were used to compare treatments and included control vs. supplementation, safflower vs. soybean meal, and the mean of these 2 supplements vs. the combined supplement.

\section{Results}

\section{Standing Crop, Forage and Diet Quality}

Standing crop estimates remained above $1450 \mathrm{~kg} \mathrm{ha}^{-1}$ throughout the study (Table 3). Stocking rates based on SCS guidelines did not seem to result in removal of appreciable amounts of forage and results may be affected by this condition (see also Grings et al. 2002). An usually large amount of precipitation in 1993 may have influenced the results of this experiment. Forage quality did decline throughout the grazing season in all years, but stayed above $6.5 \%$ CP in 1993, compared with falling below $5.5 \%$ CP in 1994 and 1995.

Diet quality declined as the grazing season progressed (Table 4). Quality declined more slowly in 1993 due to exceptionally cool and wet conditions. Dietary CP was less than $7 \%$ in late summer 1995 and

Table 4. Diet quality ( \pm SE) throughout the summer grazing season over 3 years determined from esophageal extrusa of yearling heifers.

\begin{tabular}{|c|c|c|c|c|c|}
\hline & \multicolumn{4}{|c|}{ Month } & \multirow[b]{2}{*}{ September } \\
\hline & May & June & July & August & \\
\hline \multicolumn{6}{|c|}{ Crude protein, \% of OM } \\
\hline 1993 & $18.9 \pm 0.61$ & $13.2 \pm 0.34$ & $11.5 \pm 0.29$ & $10.6 \pm 0.24$ & $9.2 \pm 0.29$ \\
\hline 1994 & $19.2 \pm 0.56$ & $14.6 \pm 0.86$ & $9.7 \pm 0.48$ & $8.7 \pm 0.20$ & - \\
\hline 1995 & $14.5 \pm 0.33$ & $11.0 \pm 0.23$ & $9.6 \pm 0.32$ & $6.8 \pm 0.19$ & $6.3 \pm 0.16$ \\
\hline \multicolumn{6}{|c|}{ IVOMD $\$ \%$} \\
\hline 1993 & $71.2 \pm 1.45$ & $65.6 \pm 0.78$ & $62.3 \pm 1.13$ & $59.7 \pm 0.52$ & $58.1 \pm 0.36$ \\
\hline 1994 & $69.3 \pm 3.72$ & $64.8 \pm 1.43$ & $56.0 \pm 1.46$ & $53.5 \pm 0.95$ & - \\
\hline 1995 & $76.4 \pm 0.44$ & $65.6 \pm 0.61$ & $61.6 \pm 0.87$ & $53.8 \pm 0.54$ & $49.5 \pm 0.67$ \\
\hline \multicolumn{6}{|c|}{$\mathrm{NDF}, \%$ ठf $\mathrm{OM}$} \\
\hline 1993 & $59.6 \pm 2.42$ & $70.8 \pm 1.18$ & $76.4 \pm 1.30$ & $79.4 \pm 0.73$ & $82.8 \pm 0.63$ \\
\hline 1994 & $61.8 \pm 1.24$ & $72.0 \pm 1.49$ & $77.1 \pm 0.70$ & $80.8 \pm 0.40$ & - \\
\hline 1995 & $60.2 \pm 1.39$ & $70.8 \pm 0.93$ & $75.1 \pm 0.92$ & $78.2 \pm 0.69$ & $79.0 \pm 0.59$ \\
\hline \multicolumn{6}{|c|}{$\mathrm{ADF}, \%$ of $\mathrm{OM}$} \\
\hline 1993 & $33.8 \pm 1.43$ & $42.5 \pm 0.89$ & $45.5 \pm 0.74$ & $48.8 \pm 0.35$ & $52.4 \pm 0.47$ \\
\hline 1994 & $37.3 \pm 0.82$ & $42.0 \pm 1.00$ & $47.7 \pm 0.56$ & $51.5 \pm 0.44$ & - \\
\hline 1995 & $37.2 \pm 0.77$ & $44.7 \pm 0.84$ & $46.2 \pm 0.74$ & $48.3 \pm 0.69$ & $49.9 \pm 0.39$ \\
\hline \multicolumn{6}{|c|}{$\mathrm{ADL}, \%$ of $\mathrm{OM}$} \\
\hline 1993 & $3.5 \pm 0.20$ & $4.8 \pm 0.30$ & $5.2 \pm 0.21$ & $5.7 \pm 0.13$ & $6.0 \pm 0.11$ \\
\hline 1994 & $4.1 \pm 0.23$ & $5.1 \pm 0.15$ & $5.6 \pm 0.09$ & $6.1 \pm 0.10$ & - \\
\hline 1995 & $3.7 \pm 0.14$ & $5.5 \pm 0.12$ & $6.1 \pm 0.15$ & $6.2 \pm 0.12$ & $6.9 \pm 0.25$ \\
\hline \multicolumn{6}{|c|}{ ADIN, \% of total $N$} \\
\hline 1993 & $8.2 \pm 0.96$ & $14.4 \pm 0.80$ & $18.7 \pm 1.66$ & $22.6 \pm 0.55$ & $24.4 \pm 0.44$ \\
\hline 1994 & $10.6 \pm 0.36$ & $8.2 \pm 2.24$ & $21.5 \pm 0.88$ & $19.8 \pm 1.24$ & - \\
\hline 1995 & $6.1 \pm 0.24$ & $8.4 \pm 0.82$ & $7.54 \pm 0.50$ & $11.7 \pm 1.36$ & $10.6 \pm 0.45$ \\
\hline
\end{tabular}

${ }^{1} \mathrm{IVOMD}=$ in vitro organic matter digestibility; $\mathrm{NDF}=$ neutral detergent fiber; $\mathrm{ADF}=$ acid detergent fiber; $\mathrm{ADL}=$ acid detergent lignin; $\mathrm{ADIN}=$ acid detergent insoluble nitrogen.

${ }^{2} \mathrm{OM}=$ organic matter. 
IVOMD had declined to less than 50\% toward the end of the experiment. Dietary crude protein (OM basis) at the time supplementation began was $10.6 \%$ in 1993 , $9.7 \%$ in 1994 , and $9.6 \%$ in 1995 .

\section{Experiment 1}

In Experiment 1, which was conducted to determine if late summer protein supplementation improved weight gain in grazing steers, unsupplemented steers did not differ in live-weight (Table 5; P > $0.10)$ at the end of grazing from supplemented steers. In 1995, weight gain did not differ ( $P>0.10$; Table 6) for steers fed the high protein supplement compared with either the control or moderate protein supplement groups.

Steers gains averaged $1.4 \mathrm{~kg}$ day $^{-1}$ during early summer (Table 5$)$ and less $(0.8$ $\mathrm{kg} \mathrm{day}^{-1}$ ) during late summer. Rate of gain differed among years for both periods. Treatment by year interactions $(P<0.01)$ were observed because in 1993, unsupplemented steers gained $0.2 \mathrm{~kg}$ day $^{-1}$ more than supplemented steers, but in 1994 and 1995 no differences between the treatments were observed. These differences among years are partially related to differences in timing of weight gain with the average daily gain for the entire grazing period not exhibiting a treatment by year interaction $(P>0.10)$.

\section{Experiment 2}

Experiment 2 was conducted to evaluate the impact of supplementation using various protein sources on weight gain, intake, and digestibility in yearling steers. Forage standing crop values for the 3 pastures used in Experiment 2 is presented in Table 3. Digestibility and CP intake of steers were high in early summer, supporting the rapid rates of gain observed during this time (Table 7). Across years, organic matter digestibly averaged $74.6 \pm 0.47$ and $67.4 \pm 0.46 \%$ and $\mathrm{CP}$ intake averaged

Table 5. Least squares means and standard error of the mean (SEM) of weight and average daily gain of yearling steers grazing Northern Great Plains rangeland in summer with or without a protein supplement provided in late summer (Experiment 1).

\begin{tabular}{|c|c|c|c|c|c|c|}
\hline & \multicolumn{2}{|c|}{ Supplement } & \multicolumn{3}{|c|}{ Year } & \multirow[b]{2}{*}{ SEM } \\
\hline & Control & $\begin{array}{c}\mathrm{CP} \\
\text { supplement }\end{array}$ & 1993 & 1994 & 1995 & \\
\hline Number of steers & 123 & 117 & 80 & 79 & 81 & \\
\hline No of days of supplementation & - & 58 & 49 & 54 & 71 & \\
\hline Initial grazing weight, $\mathrm{kg}$ & 275 & 275 & 266 & 277 & 281 & 1.0 \\
\hline Initial supplementation weight, $\mathrm{kg}$ & 382 & 383 & 402 & 376 & 369 & 1.3 \\
\hline Final weight, $\mathrm{kg}$ & 429 & 431 & 452 & 412 & 426 & 1.6 \\
\hline Early summer ADG, $\mathrm{kg}$ day $^{-1}$ & 1.44 & 1.46 & 1.28 & 1.59 & 1.49 & 0.01 \\
\hline Late summer ADG, $\mathrm{kg}$ day $^{-1}$ & 0.83 & 0.81 & 1.02 & 0.65 & 0.79 & 0.02 \\
\hline
\end{tabular}

Table 6. Least squares means and standard error of the mean (SEM) of weight gains of control steers compared with steers fed either moderate $(26 \%)$ or high $(\mathbf{4 0 \%})$ protein supplements during 1995 (Experiment 1).

\begin{tabular}{|c|c|c|c|c|}
\hline & Control & $\begin{array}{l}\text { CP Supplement } \\
\text { Moderate }\end{array}$ & High- & SEM \\
\hline$\overline{\text { Number of steers }}$ & 41 & 40 & 53 & \\
\hline Initial grazing weight, $\mathrm{kg}$ & 282 & 277 & 281 & 1.1 \\
\hline Initial supplementation weight, $\mathrm{kg}$ & 372 & 367 & 370 & 1.9 \\
\hline Final weight, kg & 426 & 425 & 427 & 2.3 \\
\hline Early summer ADG, $\mathrm{kg}$ day $^{-1}$ & 1.51 & 1.47 & 1.46 & 0.02 \\
\hline Late summer ADG, $\mathrm{kg} \mathrm{day}^{-1}$ & 0.76 & 0.80 & 0.82 & 0.02 \\
\hline Season-long ADG, $\mathrm{kg} \mathrm{day}^{-1}$ & 1.10 & 1.11 & 1.11 & 0.01 \\
\hline
\end{tabular}

$1011 \pm 22.6$ and $963 \pm 22.3 \mathrm{~g} \mathrm{day}^{-1}$ for May and June, respectively.

For the late summer period, when supplement was provided, there were no effects of supplementation or supplement composition on live-weight gain (Table 7), forage or total intake, or forage digestibility (Table 8 ). Crude protein intake was increased $(\mathrm{P}<0.05)$ by the feeding of supplements but this did not affect $(P>0.10)$ organic matter digestibility. The lack of any effect on intake and digestibility is consistent with the lack of weight gain response to supplementation.

\section{Experiment 3}

Experiment 3 was conducted to evaluate the impact of the protein supplements used in the grazing trials on ruminal fermenta- tion characteristics of steers fed medium quality grass hay. Total volatile fatty acid concentrations averaged $66 \pm 3.1 \mathrm{mM}$ and were not affected by dietary treatment. Mean ruminal ammonia was increased $(P$ $<0.05$ ) by the feeding of protein supplements, and was $2.5 \pm 0.5 \mathrm{mM}$ for the control compared with $4.4 \pm 0.5 \mathrm{mM}$ for the protein supplement treatments. A treatment by hour interaction $(P<0.05)$ was primarily related to the fact that the lesser concentrations for ruminal ammonia in control animals occurred mostly within the first 12 hours after supplementation. No differences $(P>0.10)$ in mean ruminal ammonia concentrations among protein supplement treatments were observed. Although ruminal ammonia was increased by supplementation, supplementation had no impact $(P>0.05)$ on other measures of

Table 7. Least squares means of weight and average daily gain (ADG) and standard error of the mean (SEM) of control steers compared with steers fed protein supplements containing safflower meal (SFM), soybean meal (SBM) or a combination of the 2 meals in late summer during 1993 and 1994.

\begin{tabular}{|c|c|c|c|c|c|c|c|}
\hline & \multicolumn{4}{|c|}{ Protein supplemented } & \multicolumn{2}{|c|}{ Year } & \multirow[b]{2}{*}{ SEM } \\
\hline & Control & SFM & SBM & SFM+SBM & 1993 & 1994 & \\
\hline Number of steers & 29 & 27 & 26 & 27 & 55 & 54 & \\
\hline Initial grazing weight, kg & 272 & 269 & 270 & 268 & 263 & 276 & 1.6 \\
\hline Initial supplementation weight, $\mathrm{kg}$ & 378 & 378 & 378 & 378 & 393 & 363 & 2.1 \\
\hline Final weight, kg. & 415 & 417 & 417 & 418 & 433 & 400 & 2.4 \\
\hline Early summer ADG, $\mathrm{kg}$ day $^{-1}$ & 1.23 & 1.25 & 1.25 & 1.28 & 1.19 & 1.32 & 0.02 \\
\hline Late summer $\mathrm{ADG}, \mathrm{kg}$ day $^{-1}$ & 0.70 & 0.75 & 0.76 & 0.77 & 0.81 & 0.67 & 0.02 \\
\hline Season-long ADG, $\mathrm{kg} \mathrm{day}^{-1}$ & 1.01 & 1.04 & 1.05 & 1.06 & 1.06 & 1.02 & 0.01 \\
\hline
\end{tabular}




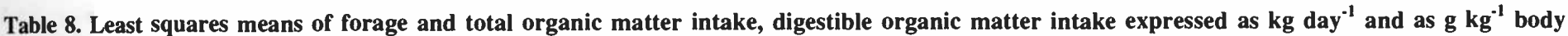
weight (BW), total crude protein intake, and forage digestibility for steers grazing native rangeland in late summer with or without various protein supplements and standard error of the means (SEM) and probability levels of orthogonal contrasts comparing treatments.

\begin{tabular}{|c|c|c|c|c|c|c|c|c|}
\hline \multirow[b]{2}{*}{ Item } & \multicolumn{4}{|c|}{ Treatment } & \multirow[b]{2}{*}{ SEM } & \multicolumn{3}{|c|}{ Contrasts } \\
\hline & Control & SFM $^{\prime}$ & $\begin{array}{l}\text { SFM and } \\
\text { SBM }\end{array}$ & SBM & & $\begin{array}{c}\text { Control vs } \\
\text { supplemented }\end{array}$ & $\begin{array}{l}\text { SFM vs } \\
\text { SBM }\end{array}$ & $\begin{array}{c}\text { Combination vs } \\
\text { single }^{2}\end{array}$ \\
\hline $\mathrm{FOMI}^{3}, \mathrm{~kg} \mathrm{day}^{-1}$ & 8.1 & 7.8 & 8.1 & 8.0 & 0.12 & 0.549 & 0.623 & 0.569 \\
\hline $\mathrm{g} \mathrm{kg}^{-1} \mathrm{BW}$ & 20.2 & 19.5 & 20.3 & 20.0 & 0.28 & 0.693 & 0.492 & 0.415 \\
\hline TOMI, $\mathrm{kg}$ day $^{-1}$ & 8.1 & 8.2 & 8.5 & 8.3 & 0.12 & 0.419 & 0.734 & 0.545 \\
\hline $\mathrm{g} \mathrm{kg}^{-1} \mathrm{BW}$ & 20.2 & 20.5 & 21.3 & 20.9 & 0.28 & 0.273 & 0.611 & 0.400 \\
\hline Forage OMD, \% & 60.4 & 59.2 & 60.0 & 59.9 & 0.37 & 0.471 & 0.454 & 0.633 \\
\hline FDOMI, $\mathrm{kg}$ day $^{-1}$ & 5.0 & 4.7 & 4.9 & 4.8 & 0.10 & 0.538 & 0.583 & 0.616 \\
\hline $\mathrm{g} \mathrm{kg}^{-1} \mathrm{BW}$ & 12.3 & 11.6 & 12.3 & 12.2 & 0.24 & 0.604 & 0.442 & 0.485 \\
\hline TDOMI, kg day ${ }^{-1}$ & 5.0 & 4.9 & 5.2 & 5.2 & 0.10 & 0.564 & 0.400 & 0.627 \\
\hline $\mathrm{g} \mathrm{kg}^{-1} \mathrm{BW}$ & 12.3 & 12.2 & 13.0 & 12.9 & 0.24 & 0.462 & 0.291 & 0.494 \\
\hline TCPI, g day ${ }^{-1}$ & 780 & 853 & 884 & 878 & 11.3 & 0.001 & 0.434 & 0.525 \\
\hline
\end{tabular}

${ }^{1} \mathrm{SFM}=$ safflower-based protein supplement; SBM = soybean meal-based protein supplement.

${ }^{2}$ Combination of safflower and soybean meal vs. either supplement alone.

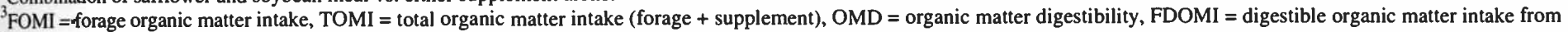
forage, $\mathrm{TDOMI}=$ total digestible organic matter intake, $\mathrm{TCPI}=$ total crude protein intake.

ruminal fermentation (data not shown) with the exception of ruminal valerate concentrations, which were increased $(\mathrm{P}<$ 0.05 ) from 0.41 to $0.56 \mathrm{mM}$ (SE $=0.009)$ with supplementation. Ruminal liquid dilution rate averaged $5.4 \pm 0.16 \%$ per hour and was not affected by treatment. Limited effects of protein supplementation on ruminal fermentation in this experiment are consistent with the lack of an effect of protein supplementation on intake, digestibility, and live-weight gain in the preceding studies in grazing steers.

\section{Discussion}

Live-weight gain patterns for steers in this study differ from previous studies at this lecation where steers lost weight in late summer (Currie et al. 1989) or where growing cattle responded to summer-long protein supplementation with increased weight gain (Grings et al. 1994). The previous studies were conducted in smaller pastures with less diverse vegetation and topography which could influence diet selection patterns. Additionally, forage availability was less than in the current study. June standing crop averaged less than $1000 \mathrm{~kg} \mathrm{ha}^{-1}$ in one of these studies (Currie et al. 1989 as reported by Haferkamp et al. 1993) compared with over $1400 \mathrm{~kg} \mathrm{ha}^{-1}$ in the current study. The lower standing crops may be related to the range sites available within pastures.

Stocking rates averaged 26 steer day ha ${ }^{-1}$, which was comparable to the previous study (Grings et al. 1994) in which cattle responded to protein supplementation. Standing crop was not measured in the study of Grings et al. (1994), however, forage availability may have been less than in the current studies because of drier conditions. Differences in experiment conditions may have resulted in differences in intake and in response to supplementation. In the previous study in which cattle responded to protein supplementation, forage organic matter intake averaged $16.4 \mathrm{~g}$ $\mathrm{kg}^{-1} \mathrm{BW}$ compared with $19.9 \mathrm{~g} \mathrm{~kg}^{-1} \mathrm{BW}$ in Experiment 2.

Cattle in a previous experiment (Grings et al. 1994) were supplemented every other day compared with every third day in the current study. While frequency of feeding generally does not affect response to supplemental protein (McIlvain and Shoop 1962), it is an important factor in supplementing energy. It may be that cattle in the study of Grings et al. (1994) were responding to the energy supplied by the supplement rather than the protein. Karn (2000) observed increased weight gains in yearling steers supplemented throughout the summer with energy but not protein while grazing Northern Great Plains rangelands in North Dakota. Length of the supplementation period may also be a factor in the different responses between studies. Additionally, younger cattle responded more to the protein supplementation than did older cattle (Grings et al. 1994).

A number of studies at other locations, primarily in the Central and Southern Great Plains, have shown positive responses in weight gains to late season protein supplementation (Phillips and Horn 1998, Lusby and Horn 1983) while others, conducted in the Northern Great Plains, have shown little to no benefit (Karn 2000). The variations in response could be related to the relative dominance of cool- versus warm-season grasses in these environments, which are known to differ in potential digestibility (Nelson and Moser 1994). In a review of research on supplementation of forage-based diets, Moore et al. (1999) found response to supplementation to be somewhat variable due to interactions among forage and supplement types. These authors suggested that the greatest responses to supplementation have been found with seeded forages, supplements with greater than $60 \%$ total digestible nutrients, and with supplemental CP intake greater than $0.05 \%$ of $\mathrm{BW}$. The supplement fed in the current study contained greater than $60 \%$ total digestible nutrients, but supplemental CP intake with the $26 \%$ protein supplement averaged less than $0.05 \%$ of BW when calculated on a daily basis. Steers supplemented with the $40 \% \mathrm{CP}$ supplement received $\mathrm{CP}$ at an average rate of $0.054 \%$ of $\mathrm{BW}$ when averaged on a daily basis. Actual feeding was at a rate of $0.16 \%$ of BW every third day

\section{Management Implications}

Rangeland forage quality in the Northern Great Plains declines as summer advances with associated increased temperature and decreased precipitation. Because of this forage quality decline, we hypothesized that every third day protein supplementation would improve weight gain in growing cattle grazing these rangelands. However, this supplementation protocol did not improve gains of steers in late summer under the conditions of this study. This lack of effect occurred with both different levels and different sources of protein. Forage intake, digestibility, and 
ruminal fermentation characteristics all supported this lack of weight gain response. A wide variety of factors can influences response to protein supplementation in grazing cattle. Increased understanding of these factors and ability to accurately estimate both cattle needs and the nutritive value of forage in extensive grazing conditions is still needed. Additional research is needed to differentiate the impact of added energy or protein on a daily basis to determine the economic viability of summer supplementation programs.

\section{Literature Cited}

AOAC. 1990. Official methods of analysis. 16 th ed. Assoc. Official Anal. Chem., Washington, D.C.

Blümmel, M., E. E. Grings, and M. R. Haferkamp. 2000. Predicting weight gain of grazing steers by the kinetics of in vitro gas production of extrusa samples fermented in nitrogen supplemented and unsupplemented incubation medium. p. 19-20 In: Proc. EAAP Satellite Symp. Wageningen, Neth.

Cochran, R.C., D.C. Adams, J.D. Wallace, and M.L. Galyean. 1986. Predicting digestibility of different diets with internal markers: evaluation of four potential markers. J. Anim. Sci. 63:1476-1483.

Currie, P.O., J.D. Volesky, D.C. Adams, and B.W. Knapp. 1989. Growth patterns of yearling steers determined from daily live weights. J. Range Manage. 42:393-396.
Goering, H.K. and P.J. Van Soest. 1970. Forage fiber analysis (apparatus, reagents, procedures, and some applications). Agr. Handbk. No. 379. USDA-ARS, Washington DC.

Grings, E.E., D.C. Adams, and R.E. Short. 1994. Protein supplementation of stocker cattle in the Northern Great Plains. J. Range Manage. 47:303-307.

Grings, E.E., R.K. Heitschmidt, R.E. Short, and M.R. Haferkamp. 2002. Intensive-early stocking for yearling cattle in the Northern Great Plains. J. Range Manage. 55:135-138.

Hach. 1987. Feed analysis manual. Hach Co., Ames, Iowa

Haferkamp, M.R., J.D. Volesky, M.M. Borman, R.K. Heitschmidt, and P.O. Currie. 1993. Effects of mechanical treatments and climatic factors on the productivity of Northern Great Plains rangelands. J. Range Manage. 46:346-350.

Heitschmidt, R. K., E. E. Grings, M. R. Haferkamp, and M. G. Karl 1995. Herbage dynamics on 2 Northern Great Plains range sites. J. Range Manage. 48:211-217.

Heitschmidt, R.K., J.D. Volesky, M.R. Haferkamp, and P.O. Currie. 1993. Steer performance on native and modified Northern Great Plains rangeland. J. Range Manage. 46:529-533.

Karn, J.F. 2000. Supplementation of yearling steers grazing Northern Great Plains rangelands. J. Range Manage. 53:170-175.

Lusby, K.S. and G. W. Horn. 1983. Energy vs protein supplementation of steers grazing native range in late summer. Okla. Agr. Exp. Sta. MP-114:209- 211 .

McIlvain, E.H. and M.C. Shoop. 1962. Daily versus every-third-day versus weekly feeding of cottonseed cake to beef steers on winter range. J. Range Manage. 15:143-146.
Moore, J.E., M.H. Brant, W.E. Kunkle, and D.L. Hopkins. 1999. Effects of supplementation on voluntary forage intake, diet digestibility, and animal performance. J. Anim. Sci. 77 (Suppl.2):122-135.

Nelson, C. J. and L. E. Moser. 1994. Plant factors affecting forage quality. p. 115-154. In: G. C Fahey, Jr. (ed) Forage Quality, Evaluation, and Utilization. ASA-CSSASSSA. Madison Wisc.

NOAA. 1993-1995. Climatological data, Montana. 96-99 (01-12). Nat. Climatol. Data Center, Asheville, N.C..

Petersen, M. K. 1987. Nitrogen supplementation of grazing livestock. p. 115-121. In: Proc. Grazing Livest. Nutr. Conf. Jackson, Wyo.

Phillips, W.A. and G.W. Horn. 1998. Supplement intake and performance of steers fed compressed block or liquid protein supplements on bermudagrass pastures. Prof. Anim. Sci. 14:36-43.

Robertson, J.B. and P.J. Van Soest. 1977. Dietary fiber estimation in concentrate feedstuffs. J. Anim. Sci. 45 (Suppl. 1):254 (Abstr.).

SAS. 1989. SAS users guide: Basics. SAS Institute, Cary, N.C.

SCS. 1983. Technical guide, Section II-E-8. 10 -14" Precipitation zone. Eastern Sedimentary Plains, Mont.

Tilley, J.M.A. and R.A. Terry. 1963. A twostage technique for the in vitro digestion of forage crops. J. Brit. Grassl. Soc. 18:104-111.

Weatherburn, M.W. 1967. Phenol-hypochlorite reaction for determination of ammonia. Anal. Chem. 39:971-974. 